\title{
Abiotic Sponge Ecology Conditions, Limski Kanal and Northern Adriatic Sea, Croatia
}

\author{
Anne Klöppel ${ }^{1}$, Corinna Messal ${ }^{2}$, Martin Pfannkuchen ${ }^{1}$, Jörg Matschullat ${ }^{2}$, Wolfgang Zucht ${ }^{1}$, \\ Bojan Hamer ${ }^{3}$, Franz Brümmer ${ }^{1}$ \\ ${ }^{1}$ Universität Stuttgart, Biologisches Institut, Abteilung Zoologie, Pfaffenwaldring, Stuttgart, Germany \\ ${ }^{2}$ Technische Universität Bergakademie Freiberg, Interdisciplinary Environmental \\ Research Centre, Brennhausgasse, Freiberg, Germany \\ ${ }^{3}$ Ruđer Bošković Institute, Center for Marine Research, Giordano Paliaga, Rovinj, Croatia \\ E-mail: joerg.matschullat@ioez.tu-freiberg.de, matschul@mailserver.tu-freiberg.de \\ Received April 1, 2011; revised April 18, 2011; accepted April 20, 2011
}

\begin{abstract}
The Limski kanal, a semi-closed inlet (channel-like bay) located on the western coast of Istria (Croatia), is an extraordinary sponge habitat. Research on the marine ecosystem has been conducted there for more than 100 years. Today, 42 valid Porifera species are described. 139 species are listed for the area around Rovinj and 159 species for the northern Adriatic Sea. While several scientists described the sponge fauna, information on the abiotic situation or an explanation for the diversity differences is missing. This study interprets physicochemical and ecological parameters including depth profiles (temperature, salinity, pH-value, oxygen, water current velocity, photosynthetically active radiation [PAR], water transparency and nutrients). Their variances are linked with the distribution patterns of the prevailing sponge fauna. The channel is characterised as predominantly marine habitat. Although a shallow sediment barrier and a headland reduce the impact of the northern Adriatic Sea, differences between the channel and the open sea seem to be limited. Compared to the more homogenous water body of the Adriatic sampling locations, the channel shows variations and gradients of ecological parameters between different locations (e.g., due to freshwater influx: nutrients, temperature, oxygen content, salinity and water current velocity) - this offering habitat diversity. The sponge fauna changes along those ecological gradients. It is dominated by the photophilic species Aplysina aerophoba and Chondrilla nucula, but sciaphilic species such as Dysidea avara, Axinella polypoides and Aplysina cavernicola can be found, too. Some specialised species (e.g., Geodia cydonium, Tethya aurantium) even populate the muddy bottom of the channel.
\end{abstract}

Keywords: Sponge Fauna, Porifera, Ecological Parameters, Abiotic Parameters, Habitat Characteristics

\section{Introduction}

\subsection{The Limski Kanal}

The Limski kanal (as of now Limski) is an $11 \mathrm{~km}$ long, semi-closed marine inlet of the Adriatic Sea at the western coast of Istria, $5 \mathrm{~km}$ north of Rovinj, Croatia (Figure 1(a)). This inlet constitutes a unique environment due to its isolated geographic position - supporting the development of endemic species of marine flora and fauna, e.g., sponges [1-3]. Examples are Tethya limski [4] and Geodia rovinjensis [5]. Situated along an E-W axis with two parallel coast lines, the channel reaches its maximum width of about $650 \mathrm{~m}$ and a maximum depth of $32 \mathrm{~m}$ at its western opening (Figures 1(b,c)). While the northern coast is sun-exposed throughout the year, the steep southern side is shaded from October through March [6].

\subsection{Ecological Characteristics of the Limski and the Northern Adriatic Sea}

Publications on ecological conditions in the Limski are rather outdated and erratic. Paul $[7,8]$ provided an overview of the sediments in both Limski and northern Adri atic Sea. He described a sediment barrier of a few meters height, separating the Limski from the open sea $[9,10]$. The bottom is composed of muddy sediments with increasing grain size towards the mouth. The channel 


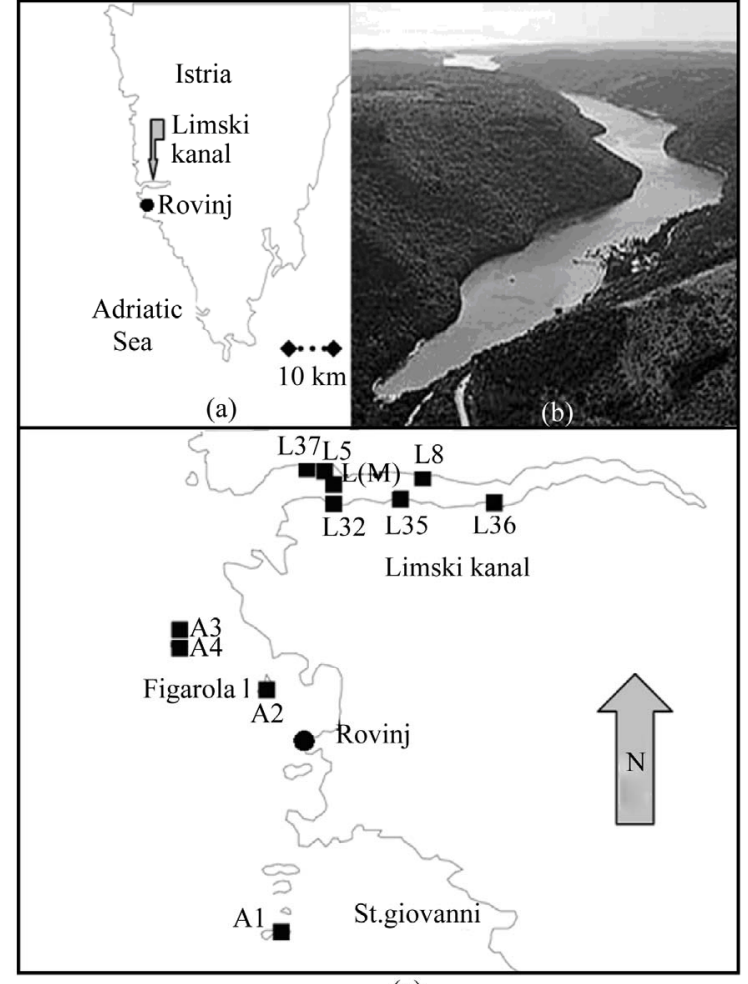

(c)

Figure 1. (a) Istrian peninsula with location of the Limski kanal and the city of Rovinj; (b) Limski kanal (www.agencija-vangogh.si/images/limski_kanal.jpg); (c) Sampling locations in Limski and northern Adriatic Sea (from Messal [53]).

flanks are slightly rising rock walls with a thin detritic layer. Wave-cut notches (30 - $40 \mathrm{~cm}$ wide) commonly occur on the northern side [6]. Elevations and rises in the posterior part result from reef-like colonies of Cladocora caespitosa [11-14]. These $C$. caespitosa reefs are very abundant in the western part of the channel and known from just a few places in the Mediterranean Sea [15]. Here, species diversity is high due to the availability of hard substrate offered by the Cladocora caespitosa benches [12].

Several ecological and hydrographical data (e.g., current velocities at the channel's opening, temperature, salinity: $36 \%$ - $38 \%$, $\mathrm{pH}$-value: 8.3 , and $\mathrm{O}_{2}$-saturation: $70 \%-100 \%$ ) were reported for the Limski [6,10,16-21]. Small creeks and springs discharge into the posterior part of the channel. Their influx becomes important during heavy rainfall periods with resulting changes in visibility (particulate matter) but do not significantly alter - besides surface runoff - temperature and salinity $[7,8,22]$. During the formation of a thermocline in spring, $\mathrm{O}_{2}$-saturation decreases to $70 \%$ near the bottom for about four months $[7,8,18]$.

Light (PAR) seems to be the most influential parame- ter for the distribution of sponges - apart from a suitable substrate for larvae settlement - because of the symbiotic association of sponges with cyanobacteria [23,24]. Müller \& Zahn [4] determined a Secchi disc-visibility [25] of 10 meters in the central section.

High terrigenous nutrient intake was reported, e.g., due to freshwater inflow in the rear part of the channel [11]. Rising DOM levels triggered an increase of planktonic organisms with a positive effect on mussel and sponge growth rates [22,24,26,27]. Enhanced sedimentation rates in the posterior part cause an additional increase of food supply and turbidity [28,29].

\subsection{Sponge Diversity and Ecology in the Limski and Northern Adriatic Sea}

Sponges are a major component of the benthic fauna in marine environments with 8,224 valid species known worldwide [30]. While most species thrive in shallow coastal waters, some are known to live in depths below 1000 m, e.g., Hexactinellida. Amongst all invertebrates, sponges provide the largest number of bioactive natural products which also could be used in human medicine [31,32]. They play a remarkable role in drug discovery. An example of successful application is avarol from $D y$ sidea avara which is used in ointments against psoriasis [33]. This sponge is also abundant in the Limski kanal.

Examinations of the sponge fauna in the waters surrounding Rovinj were pioneered by Graeffe [34], Buccich [35] and Breitfuss [36]; the latter describing the first sponges from the Limski. Further investigations on the sponge fauna of the northern Adriatic Sea near Rovinj, including the Limski, were presented by Vatova [11] and Rützler [37]. The species list for the area around Rovinj was upgraded to $139[2,3,38]$, and the species list for the northern Adriatic now contains 159 species [39]. The most recent study for the Limski describes a total number of 42 valid sponge species [12].

Distribution and abundance of sponge species are subject to a combination of abiotic and biotic parameters [40-47]. Nevertheless, publications about the channel as sponge habitat are rare, discuss a few parameters only, or are outdated. This study first summarized known ecological conditions, followed by an overview of current abiotic parameters in the Limski and the northern Adriatic Sea near Rovinj. These are correlated with distribution patterns of the prevailing sponge fauna. Parameters like photosynthetically active radiation (PAR), determined for the first time in the Limski, and recent data ( $\mathrm{pH}$-value, $\mathrm{O}_{2}$-concentration, salinity, temperature, water current velocity, water transparency, total organic carbon [TOC], dissolved organic carbon [DOC], particulate organic carbon $[\mathrm{POC}]$ ) are presented. The related experi- 
ence can be applied to determine ecological sponge preferences and plays an important role in managing closed systems for ex situ sponge cultivation to overcome the supply problem in drug discovery $[48,49]$.

\section{Material and Methods}

Detailed studies were conducted at seven locations in the Limski and four sites in the northern Adriatic Sea near Rovinj (Figure 1(c), Table 1), following a scheme by Sidri [19] and by Zucht [6]. Four locations in the Limski were selected at the western opening: L5, L32, L37, L(M), and three in the central part of the channel: L8, L35, L36. Sampling was impossible at the eastern end because of its protected character. Locations in the Adriatic Sea were chosen at the northern shore of "St. Giovanni" (A1), between the two "Figarola" islands (A2) and in the open water (A3,A4). Field campaigns for physicochemical measurements were performed in May and September 2005.

Temperature, $\mathrm{pH}$-value, $\mathrm{O}_{2}$-content and conductivity were gauged from sea surface to seafloor with a multi-parameter probe (MPP 350, WTW GmbH, Weilheim, Germany), equipped with a stirrer and a $25 \mathrm{~m}$ cable. Salinity was calculated using the Practical Salinity Scale from 1978 [50]. Light (PAR) was quantified with a quantum sensor connected to a microvolt integrator (Delta-T Devices Ltd, Cambridge, England). The probe was operated from a water-proof box (GSI Lexan Utility Box). The error caused by the Plexiglas plate was corrected by introducing a factor $(f=1.3636)$ under a defined light source. TOC, DOC and POC (= TOC - DOC) were analysed with a Shimadzu TOC-5000A analyser [51]. Current velocities were determined observing tracer droplets, injected from a syringe in front of a black benchmark, installed parallel to the main current direction [52,53]. Timing was done with a waterproof mi- cro-chronometer. Visibility was determined by Secchidisc [25].

At each location in the Limski (western opening: L5, L32, L37; central part: L8, L35, L36) horizontal belt transects with a length of 20 meters and a width of two meters at four different depths $(2,6,10,15 \mathrm{~m})$ were used to record the species and number of sponge specimen. In case of encrusting sponges (e.g., Chondrilla nucula) assumed clone patches were counted. For exact species identification by spicula preparation sponge samples were taken and stored in Ethanol for later determination.

Fisher's Alpha [54] was chosen for the quantification of sponge diversity as it is mainly influenced by the frequencies of species of medium abundances. This test is based on a log-series of the species' frequencies that we found at all locations. The results of all line transects per site were added for these calculations. The scale of $\alpha$-diversity is not clearly defined [55]. Multiple Range Test (MRT) and Fisher's least significant difference test (LSD) were applied to detect statistically significant differences between the study sites.

\section{Results}

\subsection{Current Ecological Parameters in Limski and Northern Adriatic Sea}

Measurements were taken at L32, L35, L36, L37, L(M), A3 and A4 during both field campaigns (Figure 1(c)). Water current velocity, PAR, visibility and TOC, DOC were determined in the Limski (L5, L8, L35 and L36) only. For data see Table 2. Temperatures ranged from $23.5 \pm 0.4^{\circ} \mathrm{C}$ at the surface to $17.9 \pm 0.9^{\circ} \mathrm{C}$ at $25 \mathrm{~m}$ in August and September 2005, consistently decreasing with depth (Figure 2(a)). While sampling points showed statistically significant variability, all data from the Limski showed thermocline-like discontinuity points at

Table 1. Geographical position (GPS) of the investigated sites in Limski and northern Adriatic Sea.

\begin{tabular}{|c|c|c|c|}
\hline location & GPS - north & GPS - east & description \\
\hline L 37 & $45^{\circ} 08.285^{\prime}$ & $13^{\circ} 37.775^{\prime}$ & channel entrance, north coast \\
\hline L 5 & $45^{\circ} 08.202^{\prime}$ & $13^{\circ} 38.109^{\prime}$ & channel entrance, north coast \\
\hline $\mathrm{L}(\mathrm{M})$ & $45^{\circ} 08.030^{\prime}$ & $13^{\circ} 38.200^{\prime}$ & channel entrance, centre \\
\hline L 32 & $45^{\circ} 07.896^{\prime}$ & $13^{\circ} 38.002^{\prime}$ & channel entrance, south coast \\
\hline L 35 & $45^{\circ} 07.819^{\prime}$ & $13^{\circ} 39.325^{\prime}$ & central channel, south coast \\
\hline L 36 & $45^{\circ} 07.779^{\prime}$ & $13^{\circ} 40.872^{\prime}$ & central channel, south coast \\
\hline A 1 & $45^{\circ} 02.763^{\prime}$ & $13^{\circ} 37.431^{\prime}$ & Adriatic Sea, San Giovanni island \\
\hline A 2 & $45^{\circ} 05.622^{\prime}$ & $13^{\circ} 37.132^{\prime}$ & Adriatic Sea, Figarola island \\
\hline A 3 & n. a. & n. a. & Adriatic Sea, open sea \\
\hline
\end{tabular}


Table 2. Comparison of previous and new ecological data for the Limski kanal.

\begin{tabular}{|c|c|c|}
\hline Parameters & old data & this work \\
\hline Water temperature $\left({ }^{\circ} \mathrm{C}\right)$ & $9-12 / 20-25^{[1,2]}$ & $17.9 \pm 0.9-23.5 \pm 0.4$ (June) \\
\hline Salinity (\%o) & $35-39^{[1,2,3]}$ & $35.2 \pm 0.3-36.9 \pm 0.1$ \\
\hline pH-value & $8.3^{[1,4]}$ & $8.06 \pm 0.1-8.20 \pm 0.01$ \\
\hline $\mathrm{O}_{2}$-concentration $\left(\mathrm{mg} \cdot \mathrm{L}^{-1}\right)$ & n.a. ${ }^{[5]}$ & $6.6 \pm 0.2-8.8 \pm 0.7$ \\
\hline Current velocity $\left(\mathrm{cm} \cdot \mathrm{sec}^{-1}\right)$ & $0.1-11.8^{[6]}$ & $0.8-2.2 \pm 0.9$ \\
\hline Secchi visibility (m) & $6^{[1]}, 10^{[7]}$ & $12.6 \pm 0.8$ \\
\hline $\operatorname{PAR}\left(\mu \mathrm{mol} \cdot \mathrm{m}^{-2} \cdot \mathrm{sec}^{-1}\right)$ & n.a. & $17.9-1,925.1$ \\
\hline $\mathrm{TOC}\left(\mathrm{mg} \cdot \mathrm{L}^{-1}\right)$ & n.a. & $1.8 \pm 0.7-2.1 \pm 1.5$ \\
\hline $\mathrm{DOC}\left(\mathrm{mg} \cdot \mathrm{L}^{-1}\right)$ & n.a. & $1.5 \pm 0.9$ \\
\hline
\end{tabular}

11 and $21 \mathrm{~m}$ depth. The northern Adriatic Sea was slightly warmer $\left(+1.3^{\circ} \mathrm{C}\right)$ than the channel. The temperature barely decreased to the discontinuity layer at about $18 \mathrm{~m}$ depth and showed no second irregularity. Temperature profiles could show dramatic changes of up to $2^{\circ} \mathrm{C} \cdot \mathrm{m}^{-1}$ within one meter of decreasing depth (L36).

No significant difference in salinity occurred between the Limski - L32, L35, L36, L37, L(M) - and the northern Adriatic Sea at Rovinj (A3, A4). Salinity was lower within the first 3 to $5 \mathrm{~m}$ depth of the channel compared to the sampling points of the same depth in the Adriatic Sea. Practical salinity increased at all sampling places with depth and ranged from $35.2 \pm 0.3$ to $36.9 \pm 0.1 \%$ o (Figure 2(b)). Salinity of surface waters at L37 was about $1 \%$ below average in the Limski.

In both northern Adriatic Sea and Limski, pH-values remained fairly constant to $10 \mathrm{~m}$ depth (about $\mathrm{pH} 8.2$ ). In the Limski, $\mathrm{pH}$-values remained relatively stable within the first $11 \mathrm{~m}$, then decreased to $\mathrm{pH} 8.06$ between the first and the second discontinuity layer and were stable again below $21 \mathrm{~m}$ (Figure 2(c)). In the Adriatic Sea, $\mathrm{pH}$-values remained stable to $25 \mathrm{~m}$. The homogeneous groups obtained by LSD test agreed with the channel morphology and corresponding benthic fauna [6].

Dissolved oxygen was almost identical $\left(8.8 \mathrm{mg} \cdot \mathrm{L}^{-1}\right)$ in the upper $5 \mathrm{~m}$ of the Limski and the northern Adriatic Sea (Figure 2(d)). While a slight increase $\left(9.2 \mathrm{mg} \cdot \mathrm{L}^{-1}\right)$ occurred with depth in the Adriatic Sea, the Limski showed a considerable decrease from about $8.8 \pm 0.7$ to approximately $6.6 \pm 0.2 \mathrm{mg} \cdot \mathrm{L}^{-1}$. The most pronounced changes were located between the two discontinuity points (at 11 and $21 \mathrm{~m}$ ). Oxygen content at L36 showed natural occurring fluctuations and was about $1.6 \mathrm{mg} \cdot \mathrm{L}^{-1}$ above average (data not shown).

Water current values were $2.2 \pm 0.9 \mathrm{~cm} \cdot \mathrm{sec}^{-1}$ at $5 \mathrm{~m}$

\footnotetext{
${ }^{[1]}$ Sidri [19], measurements taken in winter and summer at one depth; ${ }^{[2]}$ Gillet [20]; ${ }^{[3]}$ von Daniels [18]; ${ }^{[4]}$ Paul [7, 8]; ${ }^{[5]}$ only data in percentage of dissolved oxygen available: $70 \%-100 \%$, e.g. Sidri [19], Gillet [20], Paul [7, 8]; ${ }^{[6]}$ Kuzmanovic [21]; ${ }^{[7]}$ Müller \& Zahn [4]; n.a.: not available.
}

depth and $0.8 \pm 0.9 \mathrm{~cm} \cdot \mathrm{sec}^{-1}$ at $15 \mathrm{~m}$ depth in the Limski (L5, L8, L35, L36; Figure 3), based on 2 to 6 repetitions at four locations. Current velocities at $5 \mathrm{~m}$ depth were slightly higher than those in $15 \mathrm{~m}$ depth. There was no significant difference between the locations. Water current velocities at L36 were higher than average with 3.5 $\mathrm{cm} \cdot \mathrm{sec}^{-1}$ at $5 \mathrm{~m}$ depth and $2.1 \mathrm{~cm} \cdot \mathrm{sec}^{-1}$ at $15 \mathrm{~m}$.

PAR was measured at the water surface, and at 5, 10 and $15 \mathrm{~m}$ depth (L5,L8,L35,L36). Under exposed conditions, PAR values of about $1700-1900 \mu \mathrm{mol} \cdot \mathrm{m}^{-2} \cdot \mathrm{sec}^{-1}$ were determined at the surface, about four times higher than under shaded weather conditions (480 - 550 $\left.\mu \mathrm{mol} \cdot \mathrm{m}^{-2} \cdot \mathrm{sec}^{-1}\right)$. PAR decreased to $35 \%$ residual light intensity at $5 \mathrm{~m}$, compared with surface values, and 11\% residual light intensity at $15 \mathrm{~m}$ (Figure 3). Water transparency by Secchi disc reached $12.6 \pm 0.8 \mathrm{~m}$ in the Limski (L5, L8, L35, L36) and $12.1 \mathrm{~m}$ (A1) in the northern Adriatic Sea.

Organic carbon content was measured at location L5 and L36 (Figure 3). DOC ranged from 0.9 to $2.1 \mathrm{mg} \cdot \mathrm{L}^{-1}$ at both locations and both depths ( 5 and $15 \mathrm{~m})$, without significant differences (average Limski: $1.5 \pm 0.9 \mathrm{mg} \cdot \mathrm{L}^{-1}$ ). TOC-variability was higher, with values between 1.0 and $3.1 \mathrm{mg} \cdot \mathrm{L}^{-1}$ at 5 and $15 \mathrm{~m}$ depth (average Limski: $1.95 \pm$ $\left.1.1 \mathrm{mg} \cdot \mathrm{L}^{-1}\right)$. Differences in TOC and DOC with depth were negligible. Additional measurements at L36 in 25 $m$ depth showed an increase of TOC and DOC from 2.3 to $10.1 \mathrm{mg} \cdot \mathrm{L}^{-1}$ and from 2.0 to $4.7 \mathrm{mg} \cdot \mathrm{L}^{-1}$. Data from the northern Adriatic Sea were generally much more homogeneous than those measured in the Limski (data not shown).

\subsection{Sponge Biodiversity and Abundance in the Limski}

Sponge diversity was higher on the southern than the northern side of the channel and reached its maximum in the central part around L35 (Figure 4(a)). Biodiversity increased with depth on the southern and northern side of 

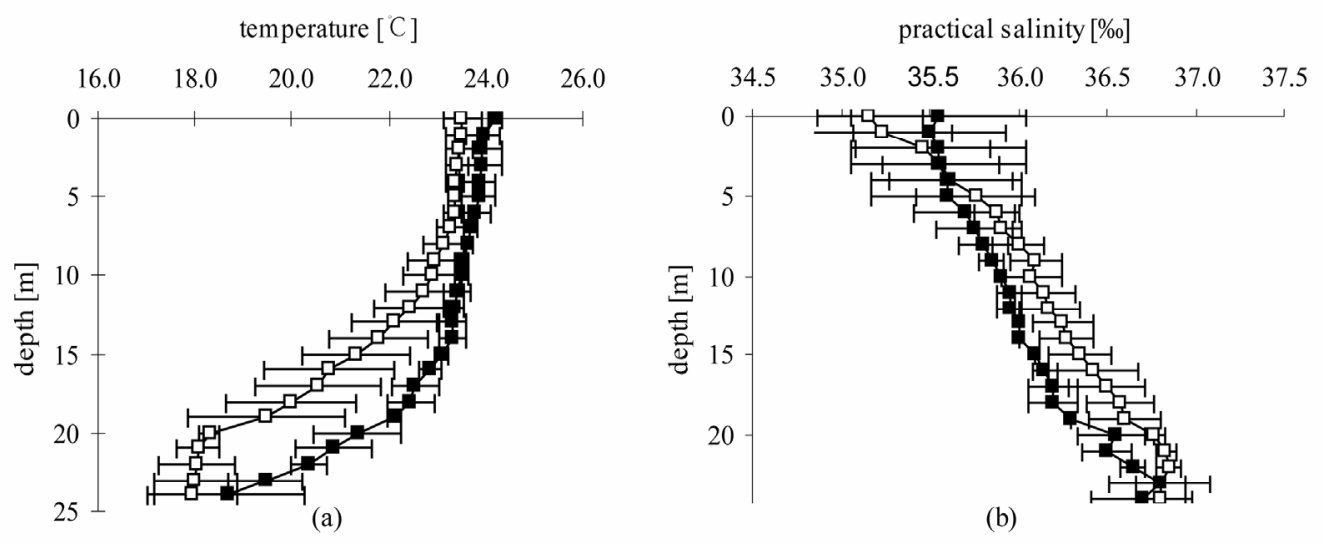

$\mathrm{pH}$ - value

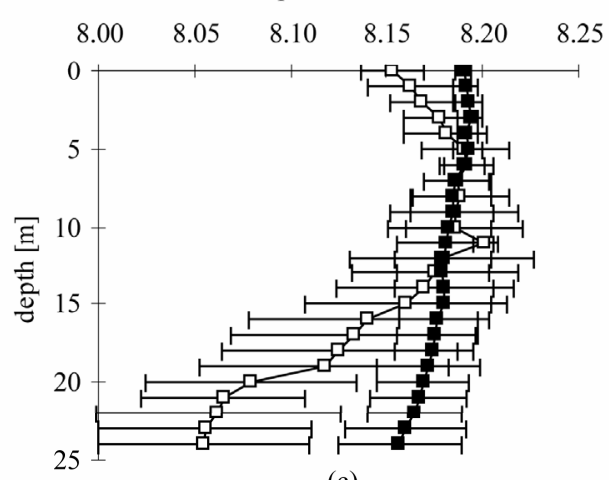

(c)

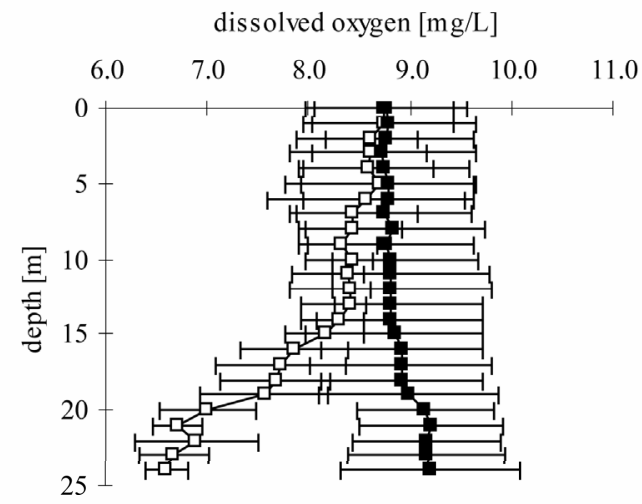

(d) $\longrightarrow$ - Limski $\longrightarrow$ Adriatic Sea

Figure 2. Parameter-depth profiles in the Limski and Adriatic Sea; a) Water temperature; b) Practical salinity, calculated from conductivity determination; c) pH-values; d) Oxygen-concentrations. Ranges depict individual values from each site at every depth.

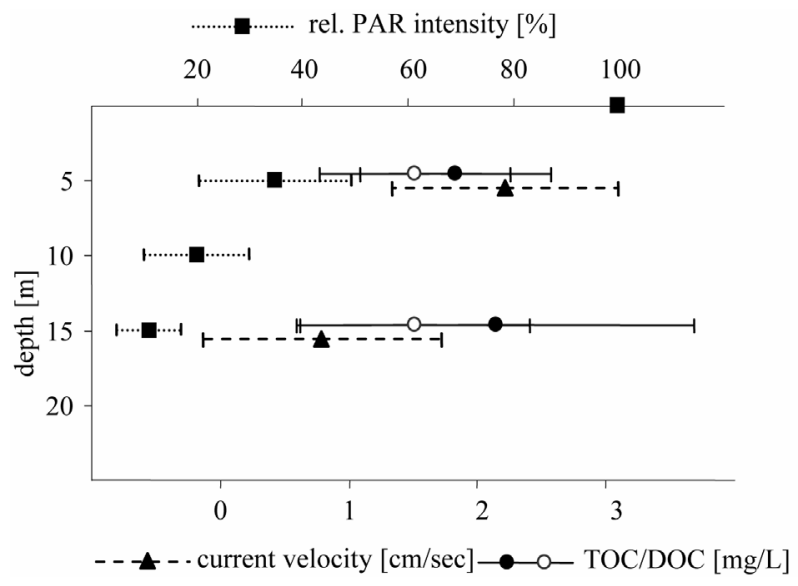

Figure 3. Depth-related parameter changes in the Limski. a) Current velocities (2-6 measurements per site); b) Relative PAR intensities, Limski 4 determinations; c) TOC (= POC + DOC), Limski 2 determinations.

the Limski (Figure 4b). At a depth of $2 \mathrm{~m}$ it was slightly higher on the northern side due to the presence of shad-

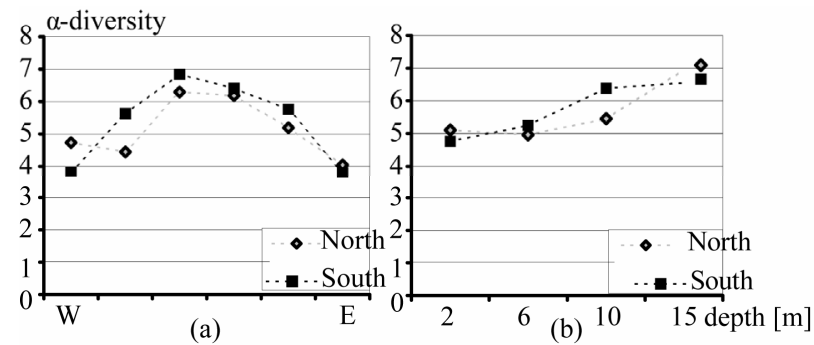

Figure 4. (a) $\alpha$-diversity (Fisher's alpha) along the Limski kanal, from the western opening (W) to the eastern end (E) on the northern and southern side. Diversity was highest in the central part at the northern coast; (b) $\alpha$-diversity increased from the surface down on both the northern and the southern side. Shading rocky protrusions close to the surface are frequent on the northern side leading to higher diversity values at a depth of $2 \mathrm{~m}$.

ing projections at the water surface. The most common species were Aplysina aerophoba, Chondrilla nucula and Chondrosia reniformis. Since the channel bottom is mud covered, sponges could only be found either loose with- 
out substrate or on stones emerging from the mud. Large specimen of Geodia cydonium and Ircinia variabilis were common. Species usually restricted to depths $>20$ $\mathrm{m}$ or caves like Axinella polypoides, Axinella cannabina and Aplysina cavernicola could be found in the Limski kanal in shallow waters as well.

Distribution patterns of the most frequent species are shown in Figures 5 and 6. They are divided into photophilic and sciaphilic species according to Rützler [56]. The fauna was dominated by photophilic species. Among these, Aplysina aerophoba and Chondrilla nucula were the most common species. Their abundance decreased continuously with depth. Only Cliona viridis specimen reached their maximal distribution at $10 \mathrm{~m}$ depth (Figure 5(a)). In shallow waters (2-6 m), the sponge community was dominated by Aplysina aerophoba and Chondrilla nucula in comparable numbers whereas further photophilic species already decreased. Several boring species (Cliona celata, $C$. nigricans and $C$. viridis) were amongst these. The number of sciaphilic specimen increased with depth (Figure 5(b)). There were species without related trend, e.g., Hemimycale columella however, an inverted trend, e.g., Chondrosia reniformis (facultative associated with cyanobacteria) that decreased with depth.

All species - especially photophilic ones - showed a decrease towards the eastern end of the channel (Figure 6). The maximum distribution was observed in the first third (predominately photophilic species, Figure 6a) and the central part (predominantely sciaphilic species, Figure 6b) of the Limski. Only Antho involvens and Hemi-

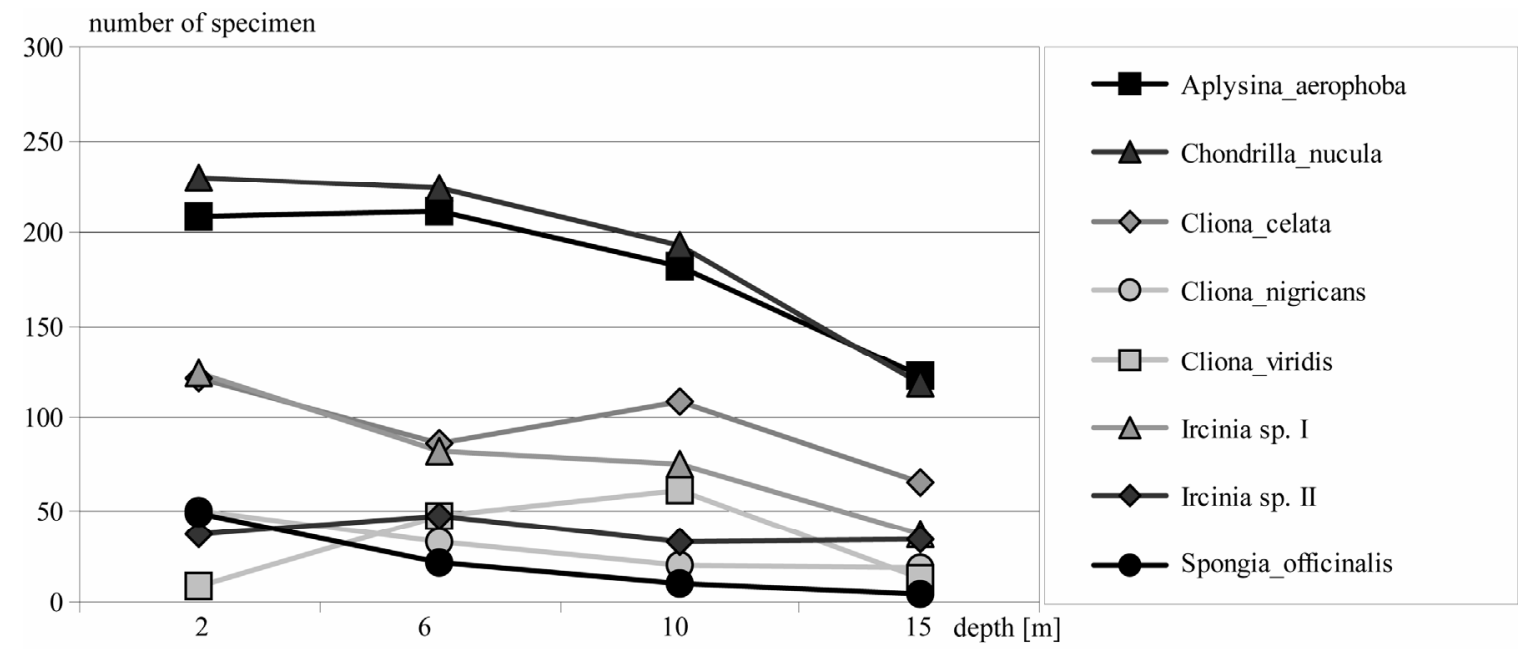

(a)

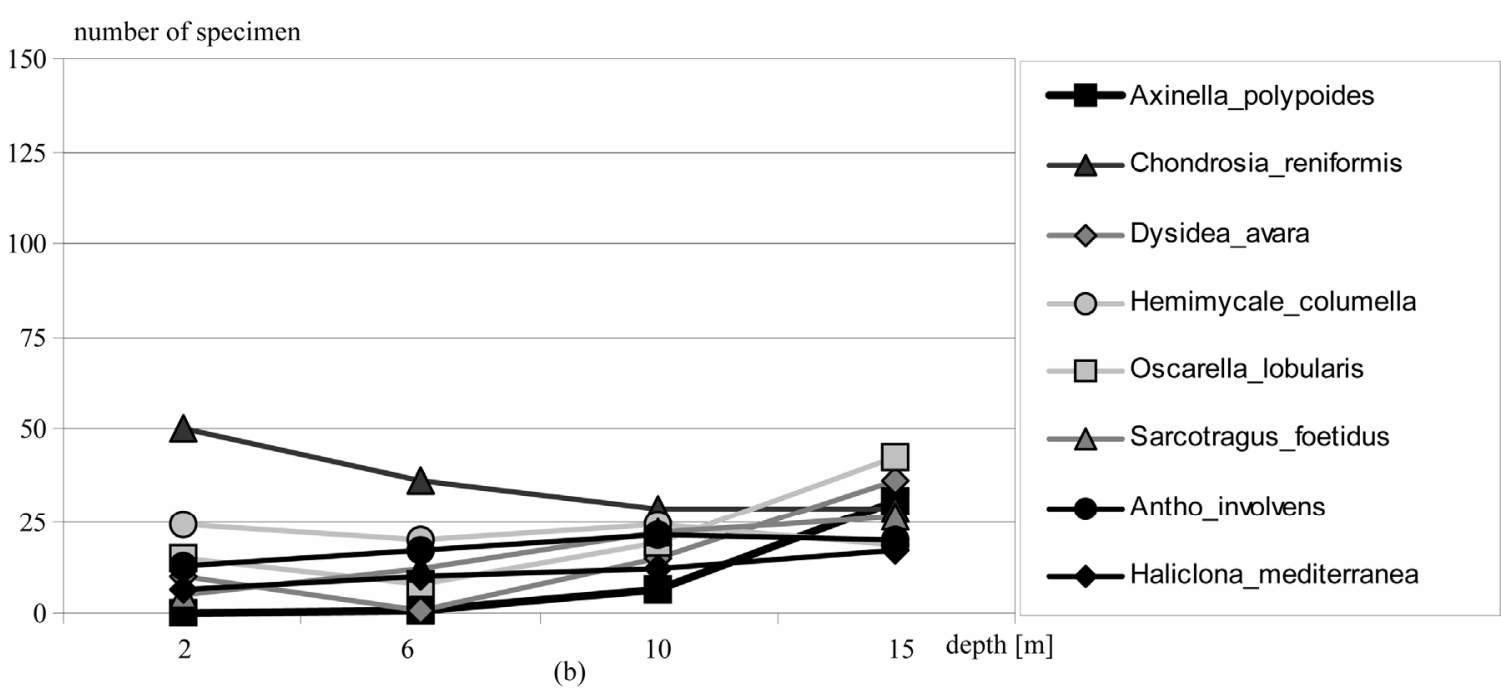

Figure 5. Number of specimen in the Limski of (a) most abundant photophilic sponge species according to depth; (b) most abundant sciaphilic sponge species according to depth. Sciaphilic species are less frequent than photophilic species. Therefore, the scale is halved in comparison to Figure 4a. Horizontal belt transects, length $20 \mathrm{~m}$, width $\mathbf{2}$ m, four different depths $(2,6$, $10,15 \mathrm{~m})$, were used to record the species and number of sponge specimen at defined measurement points $(\mathrm{L5}, \mathrm{L32}, \mathrm{L37}, \mathrm{L8}$, L35, L36) from the eastern to the western side). 
number of specimen

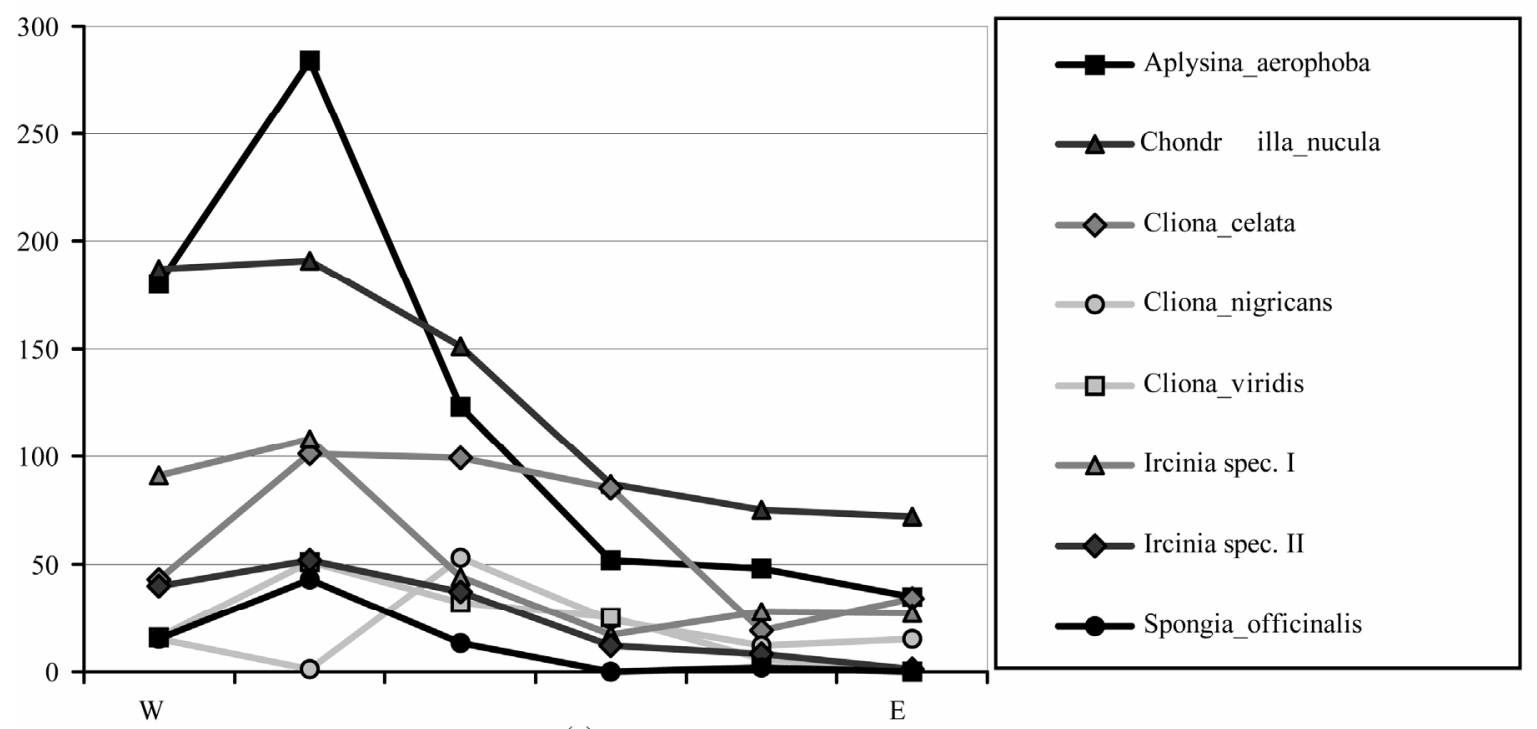

(a)

number of specimen

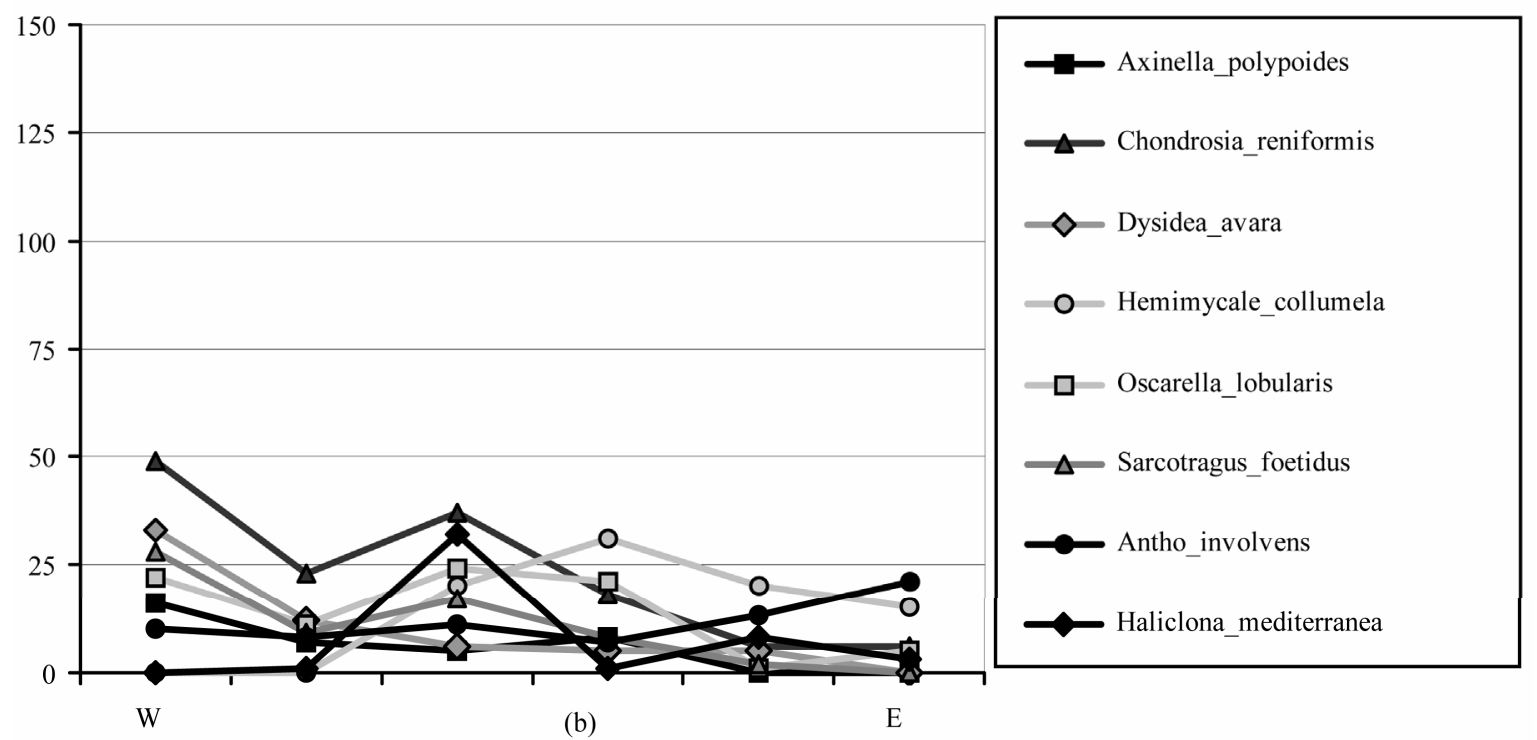

Figure 6. Number of specimen in the Limski of (a) most frequent photophilic sponge species along the Limski kanal from the western opening (W) to the eastern end $(E)$; (b) most frequent sciaphilic sponge species along the Limski kanal from the western opening $(W)$ to the eastern end $(E)$. Sciaphilic species are less frequent than photophilic species. Therefore, the scale is halved in comparison to Figure 5a. Horizontal belt transects, length $20 \mathrm{~m}$, width $2 \mathrm{~m}$, four different depths $(2,6,10,15 \mathrm{~m})$, were used to record the species and number of sponge specimen at defined measurement points $(\mathrm{L5}, \mathrm{L32}, \mathrm{L37}, \mathrm{L8}, \mathrm{L35}, \mathrm{L36})$ from the Eastern to the Western side).

mycale collumela were more frequent in the eastern section.

\section{Discussion}

Ecological and distribution differences between locations in the Limski were rather low. The Bray-Curtis similarity was around 0.45 [57]. The homogenous groups obtained through LSD test show accordance to the morphology of the channel. The Limski can be divided into three parts: the entrance [L5, L32, L37, L(M)] the central part [L8, L35, L36], and the end [begins with L36]. Differences between locations at the entrance and the end were small compared to those in the central part. The channel's end 
is only represented by a single measurement point due to its protective status and the local mariculture. With this study we show that the most influential ecological parameters on sponge distribution patterns were depth (change of PAR), sedimentation (especially in the rear part) and type of substrate, which confirms with experience described in the literature [e.g., 24,27,29].

Objectives against the application of random field models are that it is difficult to judge whether the models are well related to the spatial distribution they are supposed to describe. Also the bias caused by spatial distributions that cannot adequately be taken to be a normal realization of the used random field model is difficult to judge.

However, the fact that these methods allow subjective selected samples has lead many scientists to choose these methods. See the book by Rivoirard et al. (2000) and references therein.

\subsection{Water Column Changes along the E-W Axis}

Despite the strongest impact of the open sea at the channel's mouth, the general ecological situation does not significantly change to the eastern end. Temperature, salinity, $\mathrm{pH}-$ value and oxygen as well as visibility, PAR and organic carbon content remained similar along the E-W axis of the entire channel. The channel's opening was more affected by winds than the posterior part which is sheltered by the mountains. Wind did not exceed a light breeze (average maximum: $2.7 \mathrm{Bft}$ ) during the first field campaign, triggering small waves only (wave height ca. $0.6 \mathrm{~m}$ ). The influence of wind decreased rapidly with depth and current velocities were not affected a few meters below surface. Still, current velocities in the western part were higher compared to the central part due to the impact of the open sea. Sedimentation rates increased considerably from the northward bend of the channel (indicated in Figure 1c).

\subsection{Water Column Changes along the N-S Axis}

Temperature, salinity, $\mathrm{pH}$-values and oxygen, visibility, water current velocity and organic carbon did not change from north to south, except for PAR at 5 and $15 \mathrm{~m}$ (data not shown). While the northern side is sun-exposed throughout the year, the southern coastline is mostly shaded from the surrounding mountains. Since light, especially PAR, is highly important for many symbionts living with sponges, a difference in the faunal assemblage should be noticeable between the northern and southern coastlines (our observations, see 4.6).

\subsection{Water Column Changes with Depth}

All parameters showed changes with depth (Figure 2, 3).
Two thermocline-like discontinuity points at 11 and 21 $\mathrm{m}$ were formed with increasing surface water temperatures in spring and were nearly stable over the summer months (Figure 2(a)). This stable situation during summer had significant effects on oxygen concentrations, which remained nearly stable to $15 \mathrm{~m}$, followed by a strong decline below. Beneath $20 \mathrm{~m}$ depth, oxygen concentrations stayed constant (Figure 2(d)). The Limski yielded high oxygen amounts throughout the year with minimum saturation in summer. The homoeotherme situation during winter causes vertical mixing and even the channel's bottom is oxygenated $[7,8,18]$.

Salinity started with $35 \%$ in surface waters and increased continuously to $37 \%$ at 20 to $25 \mathrm{~m}$, suggesting a limited water exchange at those depths (Figure 2(b)). $\mathrm{pH}$-values increased to 8.2 at $11 \mathrm{~m}$ and decreased to 8.05 at $25 \mathrm{~m}$ depth. This behaviour differed from the situation prevailing at the sampling points in the Adriatic Sea and may be related to cold freshwater intrusions (see below; Figure 2(c)).

Light is the most limiting factor for the abundance of photophilic sponges at greater depths. PAR lost about $65 \%$ of its intensity at $5 \mathrm{~m}$ depth, mainly related to "red" radiation. At $15 \mathrm{~m}$ depth, PAR was almost negligible (Figure 3). Water current velocities were lower at $15 \mathrm{~m}$ compared to $5 \mathrm{~m}$ depth, reflecting a characteristic of the local current system (Figure 3).

TOC and DOC were hardly affected by depth. No difference in nutrient concentrations occurred between 5 and $15 \mathrm{~m}$, indicating a relative stable distribution (Figure 3). Obtained values (DOC: $1.5 \mathrm{mg} \cdot \mathrm{L}^{-1}$ in the Limski and the northern Adriatic) were comparable with literature data; Puddu et al. [58] found DOC contents between 0.3 and $2.0 \mathrm{mg} \cdot \mathrm{L}^{-1}$ in shallow marine systems of the Adriatic Sea.

\subsection{Special Ecological Observations for the Limski}

Some inconsistencies occurred concerning the water column in the Limski (Figures 2a-d), leading to more pronounced standard deviations of the related data as compared with corresponding data from the locations in the Adriatic Sea. Location L36 was situated near a fish and mussel farm with a research platform (BIOTECmarin). Ecological conditions at L36 differed remarkably from those at the sampling sites in the open Adriatic Sea and from the other sampling points in the Limski. Temperature fluctuations of up to $2^{\circ} \mathrm{C} \cdot \mathrm{m}^{-1}$ were detected and temperature variations of $8^{\circ} \mathrm{C}$ within one day [59], due to a displacement of the water body by currents. No significant differences compared with other sampling stations were detected for salinity and $\mathrm{pH}$-values. The oxygen content strongly increased between 1 to 
$10 \mathrm{~m}$ depth at $\mathrm{L} 36\left(10.4 \mathrm{mg} \cdot \mathrm{L}^{-1}\right)$. Water cur- rent velocities were also highest at $\mathrm{L} 36$ at $15 \mathrm{~m}$ depth $\left(3.5 \mathrm{~cm} \cdot \mathrm{sec}^{-1}\right)$. This location was likely to be influenced by the above mentioned mussel and fish farm and thus by high organic input (anthropogenic impact), as shown by the TOC/ DOC measurements [60]. Further analyses at L36 and 25 $m$ depth showed an increased TOC $\left(10.1 \mathrm{mg} \cdot \mathrm{L}^{-1}\right.$; average Limski $\left.1.95 \mathrm{mg} \cdot \mathrm{L}^{-1}\right)$ and DOC content $\left(4.7 \mathrm{mg} \cdot \mathrm{L}^{-1}\right.$; average Limski $1.5 \mathrm{mg} \cdot \mathrm{L}^{-1}$ ). This might have a positive effect on sponges. Thus, TOC increases nearby and does not decrease towards the bottom (Figure 3(c)), as mentioned by Steuer [61]. Photosynthesis and the influx of organic material through rivers and streams are additional nutrient sources [58].

Subterranean freshwater influx will be responsible for the enrichment with oxygen, some of the nutrients, and for the temperature anomalies since the temperature of these small creeks is always lower than the sea surface temperatures. Paul [7], Uffenorde [22] and Kuzmanovic [21] also mentioned the river and spring discharge in the posterior part of the channel. In contrast to their conclusions, the water body is affected by these influences. The decreased salinity in surface waters (Figure 2(b)) compared with the sampling points in the Adriatic Sea supports the influence of surface runoff.

Location L36 is characterised by a very diverse and abundant sponge fauna. Due to the karst formations of the Croatian coast, freshwater enters the ocean throughout the year, following rainfall events. Sponges seem to tolerate rapid changes of the physicochemical parameters, because they even dominate areas ("unique habitats") under freshwater influx [6].

Except for light exposition and water transparency, which were largely similar at all locations, the Limski appears to be a heterogeneous habitat. Fluctuations of abiotic factors were highest variations in the central part (L36) where sponge diversity was largest) while the western part was more homogenous.

\subsection{Limski Versus Adriatic Sea}

The observation points in the Adriatic Sea were more exposed and consequently more affected by winds (e.g., Bora) than those in the Limski kanal, since no natural barriers moderate wind force [22]. The wave movement in the Limski is much smaller than in the Adriatic Sea [28]. Thus, the water body is well mixed and more homogenous than the Limski [62]. This can be seen in the continuous constancy of all parameters in the Adriatic from 0 to $25 \mathrm{~m}$ depth (Figure 2a-d). If considered as two self contained systems, local influences (e.g., freshwater influx) on the water column were more distinctive in the Limski. Not all sponge species described for the northern Adriatic Sea could be found in the Limski (e.g., Asbesto- pluma sp., Mycale tunicata), probably due to a limited variety in adequate substrates and special habitats (e.g., caves, soft bottom). The Adriatic seafloor is composed of more coarse grained material while sediments in the Limski are smaller in size - sometimes mud - and exposed to higher sedimentation rates and therefore less favourable for larvae settlement. Only the channels mouth yielded sediments similar to those of the northern Adriatic Sea. While the Adriatic Sea generally offers a higher number of different habitats than the Limski (e.g., caves, different substrates), the new data show much accordance between the inside of the channel and sampling places outside.

The Limski must be characterised as a dominantly marine habitat, despite the sediment barrier and the headland separating the channel from the open water of the Adriatic Sea. Both northern and southern side show a good agreement concerning hydrographical data [7]. The channel itself can be divided into three sections: i) the western entrance, mostly influenced by the Adriatic Sea, ii) the central part of the channel with minimal water movement, and iii) the eastern end, characterised by small grained particles forming a muddy bottom, and easy water mixing due to low width and depth. Minor ecological gradients occur from west to east, from north to south (especially PAR - due to the orientation of the channel) and from the water surface to the bottom. Both distribution and abundance of most of the 42 Porifera species were linked to those gradients [6]. The interacttion of several parameters may influence species diversity.

\subsection{Sponge Fauna}

Brümmer et al. [12] provided the most recent overview on the sponge fauna in the Limski. Several authors also investigated the benthos in the northern Adriatic Sea [37, $38,56]$. Challenges that a sponge normally faces are related to ecological conditions such as light exposure, currents and sedimentation. Due to the limited depth of 25-30 m, photophilic species were most common (Aplysina aerophoba, Chondrilla nucula and different "Keratosa" sponges). Chondrosia reniformis, but also Tethya citrina, Tethya aurantium, Dysidea avara, Axinella polypoides and Petrosia ficiformis were also very abundant species in the Limski .

Sponge diversity in the Limski was highest in the central part of the channel (around L36), compared to its western entrance (high water movement affected by the Adriatic Sea) and eastern end (high sedimentation, muddy bottom) (Figure 4a). Here, only Cladocera casepitosa benches (often settled by Terpios gelatinosa, abundant from the center to the eastern end) provided adequate substrate [12]. 
Both coastlines ( $\mathrm{N}$ and $\mathrm{S}$ ) show decreasing abundance (Figure 5) but increasing diversity (Figure 4(b)) of most sponges with depth (to $15 \mathrm{~m}$ ). Green algae are their strongest competitors in well-lit areas and their abundance is slightly higher at the northern than the southern coast [56]. Thus, the most frequent photophilic species have a higher biodiversity and abundance in the shallow waters of the southern side (6-10 m) than on the northern side to avoid the competing situation (Figures 4 and 5). The maximum biodiversity on the northern coast occurred between 10 and $15 \mathrm{~m}$. Below, values were always higher than those at comparable depths of the southern side. Due to wave-cut notches, supplying shaded areas directly under the surface $(2 \mathrm{~m})$, diversity was also highest (minimal competition with algae) when compared with the biodiversity in similar depths at the southern side (Figure 4(b)). This habitat is not only settled by sciaphilic sponges but also by most common photophilic species, albeit in lower numbers. A similar situation is reported from caves on the islands Banjole, Sv. Katarina and Sv. Ivan in the Adriatic Sea [56,63].

The western channel opening is exposed to the water movements of the Adriatic Sea (for current velocity see Figure 3). Thus, mainly current-resistant encrusting sponges, e.g., Crambe crambe, Chondrilla nucula or boring ones like Cliona celata (Figures 5(a), 6(a)), were found in surface waters, whereas tall and branching ones, e.g., Axinella polypoides, settled deeper sites (Figure 5(b)). This species is able to face high sedimentation rates but low current velocities (Figure 3) due to their shape.

Light (PAR, Figure 3) acts as a limiting factor related to depth, exposure and substrate inclination. Aplysina aerophoba and Chondrilla nucula, the species with the highest abundance in both Limski and northern Adriatic Sea, are known to contain photosynthetic active cyanobacteria. Others like Petrosia ficiformis and Chondrosia reniformis (Figure 5(b)) may also live without this association in shaded places, e.g., caves. The abundance of most photophilic species like A. aerophoba and C. nucula decreased with depth in the Limski (Figure 5(a)), while that of sciaphilic ones such as $A$. polypoides and $D$. avara increased (Figure 5(b)). Although PAR was almost absent at $15 \mathrm{~m}$ depth (Figure 3), a few $A$. aerophoba specimen were found. A. polypoides and $A$. cavernicola are sciaphilic species living at depths of 25 $\mathrm{m}$ or more. They could be found from the central part to the eastern end of the Limski, even in shallow water; primarily in caves or under notches (A. cavernicola). This might be also caused by the higher turbidity in this area serving as radiation protection.

Abundance and diversity were minimal at the muddy bottom, typical for the eastern channel end. Antho invol- vens had its largest occurrence in this rear part. The high turbidity (radiation shield) may favour the distribution of sciaphilic sponges (Figure 6(b)). Most species could be found on rocks (Hemimycale columella, Sarcotragus foetidus, Aplysina aerophoba and Crambe crambe). A few Geodia cydonium specimen emerged from the bottom. They had a furry skeleton of spicula avoiding that particles block the pores. Chondrilla nucula was most abundant in the eastern part compared with other species, most likely because of its capability to produce mucus which encloses and removes particles from the sponge surface ([19], Figure 6(a)). Especially Terpios gelatinosa and Dysidea avara used the expanded C. caespitosa-benches as substrate. These observations and the higher diversity on the shaded southern side and below rocky protrusions $(\mathrm{N})$ support the hypothesis that the sponge biodiversity is inversely dependent on the availability of light and substrate [6].

Very often, two or more sponges form a stable association to avoid competition (epibiosis; e.g., Aplysina aerophoba and Chondrilla nucula). Both species share the same ecological niche. They can be found in shallow and light-rich waters, on hard or detritic bottom (Figure 5(a), $[12,47])$. Both face the problem of high sedimentation in different ways (A. aerophoba: tubular form, smooth surface; $C$. nucula: mucous trapping, rythmic contractions, $[19,64])$. Overgrown sponges may even share their aquiferous systems in some sort of cooperation [65].

The Limski kanal and the Adriatic Sea seem to be very similar in physicochemical features. Many species could be found all over the channel and the Adriatic Sea (e.g., A. aerophoba, C. nucula, Chondrosia reniformis, Cliona celata, Geodia cydonium and Ircinia spp.). This applied to Oscarella lobularis too, but this species prefers greater depths and notches. It is likely that the open water of the Adriatic Sea - despite the homogenous water characteristics - provide more small-scaled variations due to morphology of the coasts (e.g., adequate substrates) and the small islands compared to the Limski.

\section{Conclusions}

Environmental conditions, availability and type of substrate, and the interactions between the organisms define the structure of a benthic community. Presence, abundance and coverage of a species are strictly related to its adaptability to ecological conditions. Based on detected differences in sponge diversity and abundance between the sampling sites, the Limski kanal could be divided in three parts from the western opening to the eastern end and between the northern and the southern shores. The highest biodiversity was found in the central part at the 
southern coast at $6-10 \mathrm{~m}$ depth. At the light exposed northern coast, biodiversity was highest at $2 \mathrm{~m}$ depth (under shading rocky protrusions) and at $15 \mathrm{~m}$ depth. PAR, available substrate algal competition and sedimentation, water current, $\mathrm{pH}$, oxygen, temperature and salinity were the deciding ecological parameters responsible for the diverse sponge patterns. This and the higher diversity on the shaded southern side and below rocky protrusions (N) support the hypothesis of the sponge biodiversity being inversely dependent on the availability of light and substrate. A similar rich and diverse sponge fauna like in the Limski kanal was not described in the area.

\section{Acknowledgements}

This work was part of the BIOTECmarin project supported by the Federal Ministry of Education and Research (BMBF, 03F0414D) and the Universität Stuttgart. We thank Dr. R. Batel for the excellent logistic support at the Center for Marine Research (Ruđer Bošković Institute) in Rovinj, Croatia, including provision of the research vessel "Burin" with captain D. Devescovi. Furthermore we thank D. Mlinek from the Croatian Hydrometeorological Survey for providing the meteorological data of Rovinj.

\section{References}

[1] Müller, W. E. G., Batel, R., Schröder, H. C. and Müller, I.M. (2004) Traditional and modern biomedical prospecting: Part I - the history, sustainable exploitation of biodiversity (sponges and invertebrates) in the Adriatic Sea in Rovinj (Croatia). Evidence-based Complementary and Alternative Medicine 1, 71-82.

[2] Müller, W.E.G., Brümmer, F., Batel, R., Müller, I.M. and Schröder, H.C. (2003) Molecular biodiversity. Case study: Porifera (sponges). Naturwissenschaften 90, 103-120.

[3] Müller, W.E.G., Schröder, H.C., Wiens, M., PerovicOttstadt, S., Batel, R. and Müller, I.M. (2004) Traditional and modern biomedical prospecting: Part II - the benefits, approaches for a sustainable exploitation of biodiversity (secondary metabolites and biomaterials from sponges). Evidence-based Complementary and Alternative Medicine 1, 1-12.

[4] Müller, W.E.G. and Zahn, R.K. (1968) Tethya limski n. sp., eine Tethyide aus der Adria (Porifera: Homosclerophorida: Tethyidae). Senckenbergiana biologica 49, 469-478.

[5] Müller, I.M., Zahn, R.K., Zahn, G., Rijavec, M., Batel, R., Kurelec, B. and Müller, W.E.G. (1983) Description of Geodia rovinjensis n.sp. on the basis of immunological and morphological criteria. Thalassia Jugoslavica 19, 279-283.

[6] Zucht, W. (2005) Ökologie und Taxonomie als Grundlage mariner Biotechnologie am Beispiel adriatischer Po- riferen, $\mathrm{PhD}$ thesis, Universität Stuttgart, Stuttgart, Germany.

[7] Paul, J. (1970) Sedimentologische Untersuchungen eines küstennahen mediterranen Schlammbodens (Limski kanal, nördliche Adria). Geologische Rundschau 60, 205-222.

[8] Paul, J. (1970) Sedimentologische Untersuchungen im Limski kanal und vor der istrischen Küste (nördliche Adria). Göttinger Arbeiten zur Geologie und Paläontologie 7, 1-75.

[9] Schmidt, H. (1935) Die binomische Einteilung der fossilen Meeresböden. Fortschritte der Geologie und Paläontologie 12, 1-154.

[10] Hinze, C. and Meischner, D. (1968) Gibt es rezente Rot-Sedimente in der Adria? Marine Geology 6, 53-71.

[11] Vatova, A. (1928) Compendio della Flora e Fauna del Mare Adriatico presso Rovigno. Memoria R. Comitato Talassografico Italiano 143, 1-613.

[12] Brümmer, F., Calcinai, B., Götz, M., Leitermann, F., Nickel, M., Sidri, M. and Zucht, W. (2004) Overview on the sponge fauna of the Limski kanal, Croatia, Northern Adriatic Sea. Bolletino dei Musei e degli Istituti biologici dell'Universita di Genova 68, 219-227.

[13] Messer, R. (2007) Cladocora caespitosa - Vorkommen im Limski kanal, Kroatien - Verbreitung und Kontrollfaktoren, Diploma thesis, Universität Stuttgart, Stuttgart, Germany.

[14] Haßlwanter, R. (2007) Sedimentologische und ökologische Untersuchungen im Limski kanal/Kroatien, Diploma thesis, Universität Stuttgart, Stuttgart, Germany.

[15] Kruzic, P. and Pozar-Domac, A. (2003) Banks of the coral Cladocora caespitosa (Anthozoa, Scleractinia) in the Adriatic Sea. Coral Reefs 22, 536.

[16] Vatova, A. (1931) La fauna bentonica del Canal di Leme in Istria. Memoria R. Comitato Talassografico Italiano 181, 1-10.

[17] Vatova, A. and Di Villagrazia, P.M. (1950) Sulle condizioni idrografiche del Canal die Leme in Istria. Nova Thalassia 1, 1-68.

[18] Von Daniels, C.H. (1970) Jahreszeitliche ökologische Beobachtungen an Foraminiferen im Limski kanal bei Rovinj/Jugoslawien (nördliche Adria). Geologische Rundschau 60, 192-204.

[19] Sidri, M. (2004) Chondrilla nucula (Porifera, Demospongiae): An example of successful plasticity. Ecological and morphological aspects., $\mathrm{PhD}$ thesis, Universität Stuttgart.

[20] Gillet, P. (1985/1986) Annelides Polychétes des fonds meubles du Canal de Lim près de Rovinj (Yugoslavie). Thalassia Jugoslavica 21/22, 127-138.

[21] Kuzmanovic, N. (1985) Preliminarna istrazivanja dinamike vodenih masa Limskog kanala (Zavrsni izvjetstaj). Rep Institut Ruder Boškovic, OOUR Centar za istrazivanje mora, Rovinj 1-27.

[22] Uffenorde, H. (1970) Zur Ostracoden-Fauna eines marinen Schlammbodens an der istrischen Küste (Limski kanal, NW-Jugoslawien). Geologische Rundschau 60, 
223-234.

[23] Wilkinson, C.R. and Vacelet, J. (1979) Transplantation of marine sponges to different conditions of light and current. Journal of Experimental Marine Biology and Ecology 37, 91-104.

[24] Becerro, M.A. and Paul, V.J. (2004) Effects of depth and light on secondary metabolites and cyanobacterial symbionts of the sponge Dysidea granulosa. Marine Ecology Progress Series 280, 115-128.

[25] Tyler, J.E. (1968) The Secchi disc. Limnology and Oceanography 13, 1-6.

[26] Nümann, W. (1941) Der Nährstoffhaushalt der nordöstlichen Adria. Thalassia 5, 1-68.

[27] Valderrama, D. and Zea, S. (2003) Esquemas de distribución de esponjas arrecifales (Porifera) del noroccidente del golfo de Urabá, Caribe sur, Colombia. Boletín de Investigaciones Marinas y Costeras 32, 37-56.

[28] Beug, H.-J. (1977) Vegetationsgeschichtliche Untersuchungen im Küstenbereich von Istrien (Jugoslawien). Flora 166, 357-381.

[29] Zavodnik, D. (1971) Contribution to the dynamics of benthic communities in the region of Rovinj (Northern Adriatic). Thalassia Jugoslavica 7, 447 - 514.

[30] Van Soest, R.W.M., Boury-Esnault, N., John Hooper, J.N.A., Rützler, K., de Voogd, N.J., Alvarez, B., Hajdu, E., Pisera, A.B., Vacelet, J., Manconi, R., Schoenberg, C., Janussen, D., Tabachnick, K.R. and Klautau, M. (2008) World Porifera database <www.marinespecies.org/porifera $>$ (12.01.2009).

[31] Blunt, J.W., Copp, B.R., Hu, W.-P., Munro, M.H.G., Northcote, P.T. and Prinsep, M.R. (2007) Marine natural products. Natural Product Reports 24, 31-86.

[32] Sipkema, D., Franssen, C.R., Osinga, R., Tramper, J. and Wijffels, R.H. (2005) Marine sponges as pharmacy. Marine Biotechnology 7, 142-162.

[33] Müller, W.E.G., Schatton, W.F.H. and Gudrum, M. (1991) Verwendung von Avarol oder dessen Derivaten zur Bekämpfung von entzündlichen systemischen und dermatologischen Erkrankungen. International Patent Application DE 1991-4137093.

[34] Graeffe, E. (1882) Übersicht der Seethierfauna des Golfes von Triest. Arbeiten aus den zoologischen Instituten der Universität Wien und der zoologischen Station in Triest 4, 313-321.

[35] Buccich, G. (1886) Alcune spugne dell'Adriatico sonosciute e nuove. Bolletino della Società Adriatica di Scienze Naturali in Trieste 9, 222-225.

[36] Breitfuss, L.L. (1897) Catalog der Calcarea der Zoologischen Sammlung des Königlichen Museums für Naturkunde zu Berlin. Archiv für Naturgeschichte: Zeitschrift für systematische Zoologie 63, 205-226.

[37] Rützler, K. (1967) Liste und Verteilung der Poriferen aus der Umgebung von Rovinj. Thalassia Jugoslavica 3, 79-87.

[38] Müller, W.E.G., Zahn, R.K., Kurelec, B. and Müller, I.M. (1984) Catalogue of the sponges near Rovinj. Thalassia
Jugoslavica 20, 13 - 23.

[39] Pansini, M. and Longo, C. (2003) A review of the Mediterranean Sea sponge biogeography with, in appendix, a list of the demosponges hitherto recorded from this sea. Biogeographia 24, 57-73.

[40] Rützler, K. (1965) Substratstabilität im marinen Benthos als ökologischer Faktor, dargestellt am Beispiel adriatischer Porifera. Internationale Revue der gesamten Hydrobiologie 50, 281-292.

[41] Barnes, D.K. (1999) High diversity of tropical intertidal zone sponges in temperature, salinity and current extremes. African Journal of Ecology 37, 424-434.

[42] Bell, J.J. and Barnes, D.K.A. (2000) The distribution and prevalence of sponges in relation to environmental gradients within a temperate sea lough: Inclined cliff surfaces. Diversity and Distributions 6, 305-323.

[43] Bell, J.J. and Barnes, D.K.A. (2000) The influences of bathymetry and flow regime upon the morphology of sublittoral sponge communities. Journal of the Marine Biological Association of the United Kingdom. 80, 707-718.

[44] Bell, J.J. and Barnes, D.K.A. (2000) The distribution and prevalence of sponges in relation to environmental gradients within a temperate sea lough: Vertical cliff surfaces. Diversity and Distributions 6, 283-303.

[45] Bell, J.J., Barnes, D.K.A. and Shaw, C. (2002) Branching dynamics of two species of arborescent demosponge: The effect of flow regime and bathymetry. Journal of the Marine Biological Association of the United Kingdom 82, 279-294.

[46] Bell, J.J., Barnes, D.K.A. and Turner, J.R. (2002) The importance of micro and macro morphological variation in the adaptation of a sublitoral demosponge to current extremes. Marine Biology 140, 75-81.

[47] Zucht, W., Sidri, M., Brümmer, F., Jaklin, A. and Hamer, B. (2008) Ecology and distribution of the sponge Aplysina aerophoba (Porifera, Demospongiae) in the Limski kanal (Northern Adriatic Sea, Croatia). Fresenius Environmental Bulletin 17, 890-901.

[48] Proksch, P., Ebel, R., Edrada, R.A., Wray, V. and Steube, K. (2003) Bioactive natural products from marine invertebrates and associated fungi. In: Müller, W.E.G. (ed), Sponges (Porifera), Springer Verlag, Berlin, pp. 117-142.

[49] Hart, J.B., Lill, R.E., Hickford, S.J.H., Blunt, J.W. and Munro, M.H.G. (2000) The halichondrins: Chemistry, biology, supply and delivery. In: Fusetani, N. (ed), Drugs from the sea, Karger, Basel, Switzerland, pp. 134-153.

[50] Lewis, E.L. and Perkin, R.G. (1978) Salinity: Its definition and calculation. Journal of Geophysical Research 83, 466-478.

[51] (1997) Anleitung zur Bestimmung des gesamten organischen Kohlenstoffs (TOC) und des gelösten organischen Kohlenstoffs (DOC), in DIN EN 1484. Normenausschuß Wasserwesen (NAW) im DIN Deutsches Institut für Normung e.V.: Germany.

[52] Götz, M. and Leitermann, F. (2001) Videometrische Erfassung der Strömung im Nahfeld verschiedener 
Porifera Arten des westmediterranen Litorals, Student research project, Universität Stuttgart, Stuttgart, Germany.

[53] Messal, C. (2006) Abiotic characterisation of the Limski kanal, Croatia, Diploma thesis, Technische Universität Bergakademie Freiberg, Freiberg, Germany.

[54] Fisher, R., Corbet, A. and Williams, C. (1943) The relation between the number of species and the number of individuals in a random sample of an animal population. Journal of Animal Ecology 12, 42-58.

[55] Whittaker, R., Willis, K. and Field, R. (2001) Scale and species richness: towards a general, hierarchical theory of species diversity. Journal of Biogeorgraphy 28, 453-470.

[56] Rützler, K. (1965) Systematik und Ökologie der Poriferen aus Litoral-Schattengebieten der Nordadria. Zeitschrift für Morphologie und Ökologie der Tiere 55, 1-82.

[57] Bray, R.J. and Curtis, J.I. (1957) An ordination of upland forest communities of southern Wisconsin. Ecological Monographs 27, 325-349.

[58] Puddu, A., Zoppini, A. and Pettine, M. (2000) Dissolved organic matter and microbial food web interactions in the marine environment: The case of the Adriatic Sea. International Journal of Environment and Pollution 13,

$$
\text { 473-494. }
$$

[59] Klöppel, A., Pfannkuchen, M., Putz, A., Proksch, P. and Brümmer, F. (2008) Ex situ cultivation of Aplysina spp. close to in situ conditions: Ecological, biochemical and histological aspects. Marine Ecology 29, 259-272.

[60] Bihari, N., Micic, M. and Fafandel, M. (2004) Seawater quality along the Adriatic coast, Croatia, based on toxicity data. Environmental Toxicology 19, 109-114.

[61] Steuer, A. (1933) Zur Fauna des Canal di Leme bei Rovigno. Thalassia 1, 1-44.

[62] Kaufeld, L., Dittmer, K. and Doberitz, R. (1998) Mittelmeerwetter, Vol 3, Delius Klasing, Bielefeld, pp. 1-216.

[63] Riedl, R. (1966) Biologie der Meereshoehlen, Verlag Paul Parey, Hamburg und Berlin, pp. 1-636.

[64] Meyer, W., Sidri, M. and Brümmer, F. (2006) Glycohistochemistry of a marine sponge, Chondrilla nucula (Porifera, Demospongiae), with remarks on a possibly related antimicrobial defense strategy and a note on exopinacoderm function. Marine Biology 150, 313-319.

[65] Rützler, K. (1970) Spatial competition among Porifera: Solution by epizoism. Oecologia 5, 85-95. 